\title{
Empirical Study on the Performance of Initial Public Offerings in China
}

\author{
Liang Peng \\ Graduate School of Economics and Business Administration, Hokkaido University, Japan, 060-0809 \\ School of Management, Central South University, Changsha, P.R.China, 410083 \\ E-mail:liang261@pop.econ.hokudai.ac.jp
}

\begin{abstract}
We study the long-run performance of 166 IPOs listed on China's Shanghai Stock Exchanges from 2000 to 2002. We find that the average market-adjusted cumulative return and buy-and-hold return over the three years after listing are $-32.02 \%$ and $-20.88 \%$, which are both significantly negative. What's more, as an additional robustness check, we calculate wealth relatives. One year after listing, WR less than 1 and we obtain a three-year wealth relative of 0.6826, consistent with the CAR and BHAR estimates. We then use a cross-sectional analysis to explain the long-run underperformance of Chinese IPOs. The results show that the aftermarket performance is positive after listing (6 months) but thereafter returns decline. Buying A-share IPOs immediately after listing and holding the investment for three years results in negative returns and wealth relatives less than one.
\end{abstract}

Keywords: Initial Public Offering, Long-run Performance, Market Efficiency

\section{Introduction}

Since Ritter's [19] has presented convincing empirical evidence that IPOs underperform in the long-run, a number of corresponding studies have sought to reveal the existence the sever aftermarket underperformance for issuers in different countries. Aggarwal [1] and Loughran et al. [11] examine the returns on IPOs during the three years after going public for a number of countries. They equally-weight the IPOs in their respective samples and both find underperformance. Comparable results have also been found for IPOs in economies under transition such as China. From table 1, the aftermarket underperformance is not unique to the US IPO market, it also exists in a number of other countries, like Canada, Japan and so on.

Chinese stock markets expanded rapidly following the opening of securities markets in Shanghai and Shenzhen in the early 1990s. Although until now they are only 18 years old, they enjoy very high growth. The importance and newness of the markets and unique institutional features make China a special environment to conduct research on IPOs and findings from studies in other markets cannot be extrapolated to China. Some of the previous studies have noted that Chinese IPOs enjoy the world's highest initial returns at around 200-300\% [18] [4]. However, there is little research on the long-run performance of Chinese IPOs due to the data shortage and the current results on the long-run performance are mixed. Sun and Tong [20] look briefly at the long-run share returns (raw returns and Hong Kong Hang Seng Index adjusted returns) of IPOs and find stock returns show some mild improve- ments up to five years after share issue privatizations. Chan et al. [4] study 570 A-share IPOs and 39 B-share IPOs from 1993-98 and 1995-98 respectively and find that in the long-run (within three-year after listing) A-share IPOs slightly underperform the size- and/or book/market-matched portfolios while B-shares outperform the benchmark portfolios.

The contribution of this paper is to use more updated data and to present a deeper understanding of the special features in the Chinese IPO market to study the performance, especially the long-run performance computing by both the abnormal three-year cumulative returns and buy-and-hold returns of IPOs and use a cross-sectional analysis to explain the long-run underperformance of Chinese IPOs.

The rest of the paper is organized as follows: Section 2 introduces the features of China's stock markets; Section 3 presents the data and methodology for calculating the long-run returns; Section 4 provides the analysis of empirical results on the long-run returns. Section 5 examines several different hypotheses of the cross-sectional variance in abnormal returns. The summary and conclusion appear in Section 6.

\section{Features of China's Stock Market}

Following the economic reforms that began in 1978, the Chinese stock market was finally established in the early 1990s. The Shanghai Securities Exchange was opened in 1990, followed by the establishment of the Shenzhen 
Table 1. International evidence on the aftermarket performance of IPOs

\begin{tabular}{lllll}
\hline Country & Author(s) & Number of IPOs & Issuing Years & Aftermarket performance \\
\hline Australia & Lee,Taylor\& Walter(1996) & 266 & $1976-89$ & $-46.5 \%$ \\
Brazil & Aggarwal, Leal\&Hernandez(1993) & 62 & $1980-90$ & $-47 \%$ \\
Canada & Kooli and Suret(2003) & 445 & $1991-98$ & $-16.86 \%$ \\
Chile & Aggarwal, Leal\&Hernandez(1993 & 28 & $1982-90$ & $-23.7 \%$ \\
Finland & Keloharju(1993) & 79 & $1984-89$ & $-21.1 \%$ \\
Germany & Ljungqvist(1997) & 145 & $1970-90$ & $-12.1 \%$ \\
Hong Kong & M cguiness (1993) & 72 & $1980-90$ & $-18.3 \%$ \\
Japan & Cai\&Wei(1997) & 172 & $1971-90$ & $-27 \%$ \\
Korea & Kim, Krinsky\&Lee(1995) & 99 & $1985-88$ & $2.00 \%$ \\
New Zealand & Firth(1997) & 143 & $1979-87$ & $-10 \%$ \\
Sweden & Loughran,Ritter\&Rydqvist(1994) & 162 & $1980-90$ & $1.20 \%$ \\
United Kindom & Levis(1993) & 712 & $1980-88$ & $-8.1 \%$ \\
United States & Loughran\&Ritter(1995) & 4753 & $1970-90$ & $-20 \%$ \\
United States & Simon (1989) & 35 & $1926-33$ & $-39 \%$ \\
United States & Ritter (1991) & 1526 & $1975-84$ & $-29.1 \%$ \\
\hline
\end{tabular}

Stock Exchange in 1991.Chinese government tries to use the market to develop the economy, while still keep some socialist characteristics, which means the government plays a crucial role in monitoring and regulating the stock markets.

In Chinese stock market, there are several classes of share, A-shares, B-shares, H-shares, N-shares and non-tradable shares. A-shares were tradable only by domestic investors (and quoted in Yuan) whilst B-shares were tradable only by foreign investors (and quoted in US Dollars), although recently domestic investors have also been able to trade B-shares. Hand N-shares are listed on the Hong Kong and New York Stock exchanges, respectively. Non-tradable shares include those owned by the state and other state owned enterprises (legal person shares), although China started to merge this dual shareholding system in May 2002.When going public, shares not retained by the government, other enterprises or employees are sold to outside investors. There are five types of shares in China: government shares, which are held by the State Assets Management Bureau (SAMB); legal entity shares (or $\mathrm{C}$ shares), which are held by other state-owned enterprises; employee shares, which are held by managers and employees; ordinary domestic individual shares (or A-shares), which can be purchased only by Chinese citizens of the PRC on the Shanghai Securities or the Shenzhen Stock Exchange; and foreign shares, which can be purchased only by foreign investors in Mainland China (B-share), in Hong Kong (H-share), or on the NYSE (N-share). Only the A-shares and B-shares are listed on the Shanghai Securities and Shenzhen Stock Exchanges. The first three types of shares are not tradable in the official exchanges, although employee shares are allowed to be listed three years after the IPO.

\section{Data and Methodology}

We study the long-run performance of 166 IPOs listed on China's Shanghai Stock exchanges from 2000 to 2002. The data mainly from the China Centre for Economic Research and www.sse.com.cn, while the financial data and transactional data of shares (mainly daily closing prices) come from the Wind Information database.

The following criteria are used in selecting the final sample: (1) issuing firms are listed in Shanghai Stock Exchange (2) stock price data for issuers, market capitalization are available on the Wind Information database (3) common-share IPOs are selected, and exclude units, close-end funds, and real estate investment trust offerings.

To analyze the after performance of Chinese IPOs, we apply the standard event study methodology. Thus abnormal returns of our sample are computed using the Cumulative Abnormal Returns (CAR) and Buy-and-Hold Abnormal Returns (BHAR). There continues to be disagreement regarding the measurement of long-run abnormal return performance. Barber and Lyon [2], Lyon et al. [17], Kothari and Warner [10] and Fama [5] analyze the difference of these two methods, and find that there is no consensus on the preferred one. Lyon et al. [17] document that BHARs should be used if the research question is whether or not investors earn abnormal stock returns by holding stocks over a particular time horizon. While the CAR approach should be employed to answer the following question: do sample firms persistently earn abnormal monthly returns? Though CARs implicitly assume frequent portfolio rebalancing, Fama [5] justifies its use since it would produce fewer spurious rejections of market efficiency than would the use of BHARs. There also exists a greater knowledge of the distribution properties and the statistical tests for CARs. Since in China, the ma- 
jority of investors are individual investors, and they trade much more frequently than those in other markets, to guarantee the robustness of our results, we estimate the three-year abnormal return after IPO using both measures.

Research in the US has frequently used a matching firm approach to measure long-run abnormal returns. However, the small number of companies available means there would be a bias caused by the repeated use of matching companies. We therefore both measure three-year post-IPO abnormal returns relative to the Shanghai Stock Exchange A-share index, a capitalization weighted index of 166 companies and matching firms. So we build our conclusions on different methodologies, limited by the paper, we use the event time approach and use two methodologies within each approach: we first examine the cumulative abnormal returns (CARs) and Buy-and-hold returns (BHARs) with the shanghai stock exchange Index as the benchmark and then examine the cumulative abnormal returns (CARs) and Buy-and-hold returns (BHARs) with matching firms. ${ }^{1}$

We measure the monthly return to both the company $r_{i t}$ and the market over the three year period after the IPO. The market benchmark return $r_{m t}$ is the return to the Shanghai Stock Exchange A-share index or the return of the matching firms. We follow Ritter (1991) [19] and exclude the initial return at the time of the IPO. The CAR is obtained from the individual firm abnormal returns. The CAR over the 36 months from listing is the sum of the average monthly market-adjusted returns. The BHAR is the difference between the holding-period return of stock ' $\mathrm{i}$ ' and the market return:

The first measure we use is the three-year buy-and-hold market-adjusted returns (BHAR), defined as:

$$
\begin{aligned}
& \mathrm{BHR}_{\mathrm{iT}}=\prod_{\mathrm{t}=1}^{\mathrm{T}}\left(1+r_{i t}\right) \\
& \mathrm{BHAR}_{\mathrm{iT}}=\prod_{\mathrm{t}=1}^{\mathrm{T}}\left(1+r_{i t}\right)-\prod_{\mathrm{t}=1}^{\mathrm{T}}\left(1+r_{m t}\right)
\end{aligned}
$$

The mean BHAR over a period $\mathrm{T}$ is:

$$
\text { BHAR }_{\mathrm{T}}=\frac{1}{\mathrm{n}} \sum_{i=1}^{n} \text { BHAR }_{\mathrm{iT}}
$$

A simple $t$-test is employed to test the null hypothesis of zero mean market-adjusted buy-and-hold return:

$$
t=\frac{\text { BHAR }_{t}}{\sigma\left(B H A R_{i, T}\right) / \sqrt{n}}
$$

Where $\sigma\left(B H A R_{i, T}\right)$ is the standard deviation of the buy-and-hold market-adjusted returns, and $n$ is the sample

\footnotetext{
1 In China, the total number of market days of each year, less the long holidays, is about 240. However, in consistent with the study with Ritter (1991) and Loughran and Ritter (1995), we assumed that the number of market days per year is 252 and each month has 21 market days. On and from the first day of listing to the $21^{\text {st }}$ market day is the first event month and then the second, the third and so on. So, the word "month" herein refers to a market month, the word "year" to the market year and the express "three years" to 756 market days.
}

size.

The second measure we use is the three-year cumulative market-adjusted long-run performance (CAR), defined as:

$$
\begin{gathered}
C A R_{i T}=\sum_{t=1}^{T}\left(r_{i t}-r_{m t}\right) \\
C A R_{T}=\frac{1}{n} \sum_{i=1}^{n} C A R_{i T}
\end{gathered}
$$

The statistical significance of cumulative abnormal returns is tested by:

$$
t=\frac{C A R_{i t}}{\sigma\left(C A R_{i t}\right) / \sqrt{n_{t}}}
$$

Where $\sigma\left(C A R_{i t}\right)$ is the standard deviation of cumulative abnormal returns for the sample of $n$ firms and $n_{t}$ is the number of IPOs on the $t^{\text {th }}$ month.

What's more, as an additional robustness check, we calculate wealth relatives. Wealth relatives (WR) are the ratio of the end-of-period wealth from holding a portfolio of issuers to the end-of period wealth from holding the market benchmark. A wealth relative less than 1 indicates underperformance relative to the benchmark portfolio.

\section{Results on the long-run performance}

\subsection{Results on the Long-run Performance by Using Shanghai Stock Exchange Index as the Benchmark}

Tables 2 and 3 present the abnormal returns calculated using Shanghai Stock Exchange Index as the benchmark.This two tables present the mean percentage CAR and BHAR within 36 months after listing for 166 IPOs listed on the Shanghai A-share market between 2000 and 2002. The initial return at listing is excluded from the estimation of the CAR and BHAR.

From the result, IPO performance has been poor whichever method is used. For example, From Table 1 and Table 2, either method shows the IPO performancebegins to underperformed than that of the market index after 6 months of listing and the mean BHAR and CAR estimated over one year period after issue is $-3.2 \%$ (t-statistic $=-2.314)-2.05 \%(t$-statistic $=-1.259)$, over a two year period after issue is-11.37\%(t-statistic $=-5.285)$ and $-14.07 \%(t-s t a t i s t i c=-5.427)$, and a three-year period after issue is $-20.88 \%($ t-statistic $=-9.806)$ and $-32.02 \%(t-s t a t i s t i c=-9.37)$. One year after listing, WR less than 1 and we obtain a three-year wealth relative of 0.6826 .

Figure1 shows the plot of CAR, BHAR and the monthly AR for the first 36 months after the listing. It shows the IPO performance within the first months after listing slightly outperforms the market index. The continuation of this trend varies with the measurement. By CAR, the IPO performance outperforms the market index for the first nine months after listing; while with BHAR, 
Table 2. Mean of CAR and BHAR of A shares on Shanghai Stock Exchange (RA:A-Share Index of Shanghai Stock Exchange; BHRA: A- Share Index of Shanghai Stock Exchange)

\begin{tabular}{llllllll}
\hline Months/Return & RIPO & RA(2) & CAR (3) $=(1)-(2)$ & BHRIPO (4) & BHRA (5) & BHAR (6)=(4) $-(5)$ & WR \\
\hline $0-1$ & -0.9996 & -0.9962 & -0.0034 & 1.0002 & 1.0042 & -0.004 & 0.9963 \\
$0-3$ & -0.9817 & -0.9841 & 0.01245 & 1.0174 & 1.0042 & 0.0132 & 1.0118 \\
$0-6$ & -1.0033 & -1.0168 & 0.0135 & 0.9874 & 0.9798 & 0.0076 & 1.0048 \\
$0-12$ & -1.1367 & -1.1162 & -0.0205 & 0.8471 & 0.8791 & -0.032 & 0.9581 \\
$0-18$ & -1.2489 & -1.181 & -0.0679 & 0.736 & 0.8069 & -0.0709 & 0.896 \\
$0-24$ & -1.3223 & -1.1816 & -0.1407 & 0.6837 & 0.8022 & -0.1137 & 0.8323 \\
$0-36$ & -1.5468 & -1.2242 & -0.3202 & 0.5407 & 0.7495 & -0.2088 & 0.6826 \\
\hline
\end{tabular}

Table 3. Mean and t-Statistic test of CAR and BHAR. ** significant at the 0.05 , *** significant at the 0.01 (significance is given by a skewness-adjusted t-statistic)

\begin{tabular}{lllllllllll}
\hline Return & Months & Mean & Media & Std. Dev & Skewness & Kurtosis & Min. & Max. & t-Statistic & Sig \\
\hline & $0-1$ & -0.004 & -0.0143 & 0.0778 & 0.5281 & -0.1944 & -0.159 & 0.2138 & 0.661 & 0.51 \\
& $0-3$ & 0.0132 & 0.0058 & 0.1278 & 1.2024 & 2.7328 & -0.2188 & 0.5064 & 1.335 & 0.184 \\
& $0-6$ & 0.0076 & 0.0014 & 0.1397 & 0.6874 & 1.0327 & -0.2541 & 0.5632 & 0.699 & 0.485 \\
BHAR & $0-12$ & -0.032 & -0.0318 & 0.1783 & -0.0367 & 0.8188 & -0.6113 & 0.4725 & $-2.314^{* *}$ & 0.022 \\
& $0-18$ & -0.0709 & -0.0751 & 0.2018 & 0.1141 & 1.8557 & -0.7564 & 0.7431 & $-4.524^{* * *}$ & 0 \\
& $0-24$ & -0.1137 & -0.1404 & 0.2772 & 1.5804 & 5.5915 & -0.76 & 1.2381 & $-5.285^{* * *}$ & 0 \\
& $0-36$ & -0.2088 & -0.2835 & 0.2743 & 1.7754 & 4.7055 & -0.6167 & 1.1777 & $-9.806 * * *$ & 0 \\
\hline & $0-1$ & -0.0034 & -0.0126 & 0.0773 & 0.3886 & -0.4122 & -0.1674 & 0.1962 & -0.569 & 0.57 \\
& $0-3$ & 0.0125 & 0.0098 & 0.1212 & 0.6578 & 1.0641 & -0.2583 & 0.4168 & 1.324 & 0.187 \\
& $0-6$ & 0.0135 & 0.0187 & 0.1407 & 0.1368 & -0.1955 & -0.2829 & 0.4385 & 1.237 & 0.218 \\
& $0-12$ & -0.0205 & -0.0043 & 0.2103 & -0.5158 & 0.9987 & -0.7396 & 0.4309 & -1.259 & 0.21 \\
& $0-18$ & -0.0679 & -0.058 & 0.2637 & -0.6502 & 1.822 & -1.1305 & 0.6636 & $-3.319 * * *$ & 0.001 \\
& $0-24$ & -0.1407 & -0.1436 & 0.334 & 0.15 & 1.2852 & -2.2523 & 0.9658 & $-5.427 * * *$ & 0 \\
& $0-36$ & -0.32 .2 & -0.3499 & 0.4403 & 0.3586 & 0.1121 & -1.5934 & 1.0116 & $-9.37 * * *$ & 0 \\
\hline
\end{tabular}

IPO performance outperforms the market index for the first 6months after listing. Although there is a little difference between the long-run abnormal returns by these two measurements, the overall trends are consistent: the IPO performance outperforms the market index within a short period after listing, but it is poor than the market index in the long run. In addition, from the AR of each individual month, the IPO performance is almost equal to the market index within the first nine months after listing, but it drops significantly in the $10^{\text {th }}$ month and then continues to keep equal to the market index. However, its performance for every month after the $16^{\text {th }}$ month is significantly poor than the market index.

\subsection{Results on the Long-run Performance by Using Matching Firms}

Research in the US has frequently used a matching firm approach to measure long-run abnormal returns. So we also compute the long-term abnormal return with the matching firms. Our reference portfolios are formed continually on the basis of firm size. To construct the size control portfolio, all Chinese stocks are ranked each month according to their market capitalization, and four quartile portfolios are formed.

From Table 4, within one-year, results of abnormal return of an IPO computing by CAR and BHAR begin to show big deviations. The one-year period CAR is $-10.89 \%$, but the one-year period BHAR is only $-6.14 \%$.

In addition, the differences between the 0-18 month, two-year and three-year period CAR and BHAR are even bigger, especially the two-year and the three-year abnormal returns. The deviations in these two methods results in the matching firm will be adjusted at the end of each year. For the same sample firm, the matching firm is different and there are big differences between the market prices of different matching firms. When different matching firms are linked at the end of each year, big differences may appear between the closing price of the last market day of the previous year and the closing price of the first market day of another matching firm for the current year, thus making the return of the first market day of the current year to be very small or very big. BHAR is obtained using the continuous multiplication, so this makes the results unreliable. On basis of this, when using the return of the matching firm to calculate the 


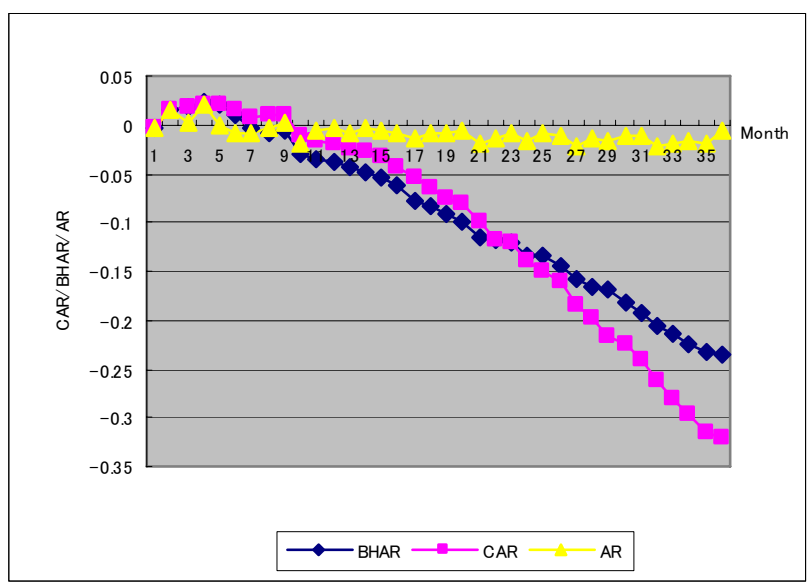

Figure 1. Three Year AR, CAR and BHAR for IPOs listed in 2000-2002

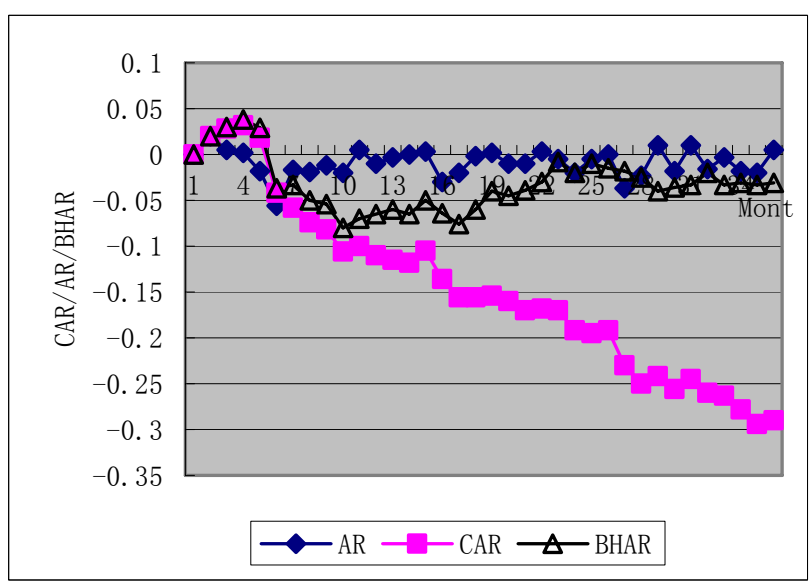

Figure 2 Three Year AR, CAR and BHAR for IPOs listed in 2000-2002

Table 4. Mean of CAR and BHAR of A shares on Shanghai Stock Exchange (BHRm: m-matching firm)

\begin{tabular}{cccccccc}
\hline Months/Return & IPO & Matching firm & CAR & BHRIPO & BHRm & BHAR & WR \\
\hline $0-1$ & -0.9996 & -0.9976 & -0.002 & 1.0002 & 1.0027 & -0.0025 & 0.9975 \\
$0-3$ & -0.9817 & -1.0048 & 0.02307 & 1.0175 & 0.9905 & 0.0269 & 1.0273 \\
$0-6$ & -1.0033 & -0.9608 & -0.0426 & 0.9868 & 1.0175 & -0.0307 & 0.9698 \\
$0-12$ & -1.1367 & -1.0278 & -0.1089 & 0.8421 & 0.9035 & -0.0614 & 0.932 \\
$0-18$ & -1.2489 & -1.0938 & -0.1552 & 0.7226 & 0.7783 & -0.0558 & 0.9284 \\
$0-24$ & -1.3223 & -1.13 & 0.1923 & 0.669 & 0.6849 & -0.016 & 0.9768 \\
$0-36$ & -1.5444 & -1.2558 & -0.2886 & 0.5147 & 0.5305 & -0.0158 & 0.9702 \\
\hline
\end{tabular}

Table 5. Mean and t- Statistics of CAR and BHAR. *, ** and *** mean that it is significant at 0.1, 0.05 and 0.01

\begin{tabular}{ccccccccccc}
\hline Return & Months & Mean & Median & Std.Dev. & Skewness & Kurtosis & Min. & Max. & t-statistic & Sig. \\
\hline \multirow{6}{*}{ BHAR } & $0-1$ & -0.0025 & -0.0055 & 0.2131 & -1.515 & 10.5136 & -1.3176 & 0.6509 & -0.151 & 0.88 \\
& $0-3$ & 0.0269 & 0.0405 & 0.2782 & -0.6819 & 3.5738 & -1.2764 & 0.8272 & 1.247 & 0.214 \\
& $0-6$ & -0.0307 & 0.0111 & 0.4516 & -2.8202 & 15.2875 & -3.157 & 0.8763 & -0.875 & 0.383 \\
& $0-12$ & -0.0614 & 0.0549 & 0.47 & -1.885 & 5.3669 & -2.476 & 0.5415 & $-1.683^{*}$ & 0.094 \\
& $0-18$ & -0.0558 & 0.0251 & 0.4454 & -1.8782 & 6.323 & -2.1279 & 0.7636 & -1.613 & 0.109 \\
& $0-24$ & -0.016 & 0.0043 & 0.3925 & -1.3557 & 8.2853 & -2.3123 & 1.2539 & 0.542 & 0.601 \\
& $0-36$ & -0.0158 & -0.142 & 0.3567 & -0.0927 & 3.6216 & -1.4209 & 1.3853 & 0.57 & 0.57 \\
\hline \multirow{6}{*}{ CAR } & $0-1$ & -0.002 & -0.0043 & 0.2228 & -1.5615 & 12.0763 & -1.4026 & 0.7531 & -0.114 & 0.909 \\
& $0-3$ & 0.0231 & 0.043 & 0.2711 & -0.8661 & 4.4508 & -1.3544 & 0.8025 & 1.096 & 0.274 \\
& $0-6$ & -0.0426 & 0.0107 & 0.4551 & -2.7806 & 13.7181 & -3.0421 & 0.7497 & 1.205 & 0.23 \\
& $0-12$ & -0.1089 & 0.0076 & 0.5624 & -1.523 & 3.9671 & -2.8921 & 0.8262 & $-2.495 * *$ & 0.014 \\
& $0-18$ & -0.1552 & -0.0521 & 0.5794 & -1.3606 & 3.3573 & -2.8201 & 0.8532 & $-3.451^{* * *}$ & 0.001 \\
& $0-24$ & -0.1923 & -0.0891 & 0.6053 & -1.1468 & 2.986 & -2.818 & 1.1703 & $-4.094 * * *$ & 0 \\
& $0-36$ & -0.2886 & -0.245 & 0.7067 & -0.4151 & 0.802 & -2.4443 & 1.7588 & $-5.261 * * *$ & 0 \\
\hline
\end{tabular}

long-term performance of IPO, it is better for us to use the CAR to explain the degree of long-term underperformance of IPO.

From Table 4 and 5, the CAR over one year after listing is found to be $-10.89 \%$, with a t-statistic of $-2.495 \%$, two years after listing is found to be $-19.23 \%$ with a t-statistic of $-4.094 \%$, three years after listing is found to be $-28.86 \%$ with a t-statistic of $-5.261 \%$. The BHAR is significant at the 0.1 level only for the first year and the long-run return is $-6.14 \%$. It shows that IPO performance has been poor whichever method is used.Fig. 2 shows the plot of AR, CAR and BHAR for each month within three years. From Fig.2, for the first six months after the listing, IPO performance is slightly outperform a matching firm, 
but it is underperformed after six months. Although it rebounds after that period, but the degree is small. In the long run, the IPO performance has been poor.

\section{Explaining for the Long-run Underper- formance}

\subsection{Some Determinants with Long-run Per- formance}

Previous research has identified several factors important in explaining post-IPO performance. These incorporate the consistent evidence of investor over optimism at issue, together with the perceived riskiness of the firm and the degree to which there is information asymmetry between issuer and investor. Different from the previous studies, in this section, we conduct multivariate regression analyses to examine cross-sectional determinants of the aftermarket performance of China's IPOs from the aspect of the characteristic of a firm. For this purpose, we posit the following regression model:

$$
M A R 3=\beta_{0}+\beta_{1} \mathrm{LnTA}+\beta_{2} R S C+\beta_{3} I N D+\beta_{4} A G E
$$

MAR3: the aftermarket performance of IPOs measured by the market adjusted buy-and-hold return for the three year aftermarket period excluding the initial-return period; LnTA: the natural log of total assets before going public; RSC: the percentage of trade shares; IND: industry dummy to show the industry is high-tech or traditional; 1-traditional, 0-high-tech; AGE: the natural log of a firm's incorporation age in years at the time of the IPO.

The first fact is the size of the company. Large companies have less ex ante risk than small companies, respectively, because there is more information about them and because they are likely to be more closely monitored by government and regulatory agencies. We therefore hypothesize negative signs on the LnTA. The second fact is the percentage of tradable shares. The majority of Chinese domestic shares are nontraded shares owned by the government or by other companies, so fewer than half of all shares are tradable. We assume that smaller government holdings result in better restructuring, so the better long-run performance a listed company would expect to have. We hypothesize the positive signs on the tradable shares (RSC). The third factor is the industry effect. Like Ritter [19], we examine the industry effect on the IPO long-run returns. The variable we use is IND: a dummy variable with the value o assigned to high-tech, and traditional is 1 . If a company belongs to the high-tech industry, it is expected to enjoy high growth in the near future. However at the same time, companies with high-tech features will face more risk, which could be rewarded by better long-run performance. Therefore, we expect a positive coefficient for the high-tech dummy. The fourth factor is the company's incorporation age in years at the time of the IPO. The old companies tend to be more mature and have stable performances than the younger companies [19]. They expect to have better long-run perform- ance. So we hypothesizes it should be positively related to long-run performance.

\subsection{Cross-sectional Analysis}

In the regression analysis, the results of overall parameter of the model are presented in Table 6. The variance results of regression are presented in Table 7. the results of multivariate regressions are presented in Table8.

From Table 6, the adjusted $R^{2}$ is to increase with the improvement of model. In model 3, it is $12.6 \%$. From the regression result of Table 7 , sum of squares are from 1.173 in model $l$ to 1.763 in model 3 . the significant of $F$ is lower than 1 , it shows that the effect of regression is significant at 0.01 level.

From Table 8, three variables are in the model, and they are all at the significant of 0.05 level. As for the relationship between the company size and IPO long-run returns, the estimation results shows that it have no relationship with the long-run returns. The variable that measures the percentage of tradable shares is negative. In China, after listing, the government is still the biggest shareholder of listed companies. Unlike the developed markets, particularly the US, they suggest that the proportion retained by current shareholders reflects the demand for an IPO [6]. In China, the listing mechanism does not allow demand to feed back to either the size of issue or the issue price. Our result is consistence with Tian [21] he concludes that firm performance is positively related to government ownership when the level of owner ship is greater than approximately $30 \%$. In China, government ownership is beneficial to firms.

Turing to the relationship between the industry effects, the coefficient is 0.154 , the traditional industry have a better long-run performance. Incorporation age and long-run performance are negatively related to each other at the 0.05 significance level. This is similar to the findings in previous research (Chen\&Meng2000). Incorporation age we calculated is after the shareholding reform.

\section{Conclusions}

This paper attempts to satisfy the great interest in Chinese evidence on the long-run performance of 166 A-share IPOs on Shanghai Stock Exchange between January 2001 and 2002. The main results are the following:

(1). When we use shanghai stock exchange Index as the benchmark to calculate the CAR and BHAR of our sample within 3 years after listing, either method shows the IPO performance begins to underperformed than that of the market index after 6 months of listing and the mean BHAR and CAR estimated over one year period after issue is $-3.2 \%(\mathrm{t}$-statistic $=-2.314)-2.05 \%$ ( $\mathrm{t}$-statistic $=$ $-1.259)$, over a two year period after issue is $-11.37 \%(\mathrm{t}-\mathrm{statistic}=-5.285)$ and $-14.07 \%$ (t-statistic $=$ -5.427 ), and a three-year period after issue is $-20.88 \%$ $(\mathrm{t}$-statistic $=-9.806)$ and $-32.02 \%$ (t-statistic $=-9.37)$. 
Table 6. Results of parameter of the model

\begin{tabular}{cccccc}
\hline Modle & $\mathrm{R}$ & $\mathrm{R}$ Square & Adj.R Square & $\begin{array}{c}\text { Std.Error } \\
\text { of the Estimate }\end{array}$ & Durbin-Watson \\
\hline 1 & $0.307(\mathrm{a})$ & 0.094 & 0.089 & 0.2618 \\
2 & $0.344(\mathrm{~b})$ & 0.118 & 0.108 & 0.2591 & 1.838 \\
\hline
\end{tabular}

a Predictors:(constant), SC

b Predictors:(constant), RSC, AGE

c Predictors:(constant), RSC,AGE, IND

Table 7. Variance results of regression

\begin{tabular}{ccccccc}
\hline Model & & Sum of Squares & $\mathrm{df}$ & Mean Square & $\mathrm{F}$ & Sig. \\
\hline \multirow{2}{*}{1} & Regression & 1.173 & 1 & 1.173 & 17.108 & $0.000(\mathrm{a})$ \\
& Residual & 11.214 & 164 & 0.069 & & \\
& Total & 12.414 & 165 & & & \\
2 & Regression & 1.47 & 2 & 0.735 & 10.951 & $0.000(\mathrm{~b})$ \\
& Residual & 10.944 & 163 & 0.067 & & $0.000(\mathrm{c})$ \\
& Total & 12.414 & 165 & & & \\
& Regression & 1.763 & 3 & 0.937 & & \\
\end{tabular}

a Predictors:(constant), RSC

b Predictors:(constant), RSC, AGE

c Predictors:(constant), RSC,AGE, IND

d Dependent Variable: BHAR3

Table 8. Results of multivariate regressions: determinants of long-run performance of China's IPOs

\begin{tabular}{|c|c|c|c|c|c|c|}
\hline \multirow[t]{3}{*}{ Model } & & \multicolumn{2}{|c|}{ Unstandardized } & \multirow{2}{*}{$\frac{\text { Standardized }}{\text { Coefficients }}$} & \multirow[t]{2}{*}{$\mathrm{t}$} & \multirow[t]{2}{*}{ Sig. } \\
\hline & & Coefficients & & & & \\
\hline & & B & Std.Error. & Beta & & \\
\hline \multirow[t]{2}{*}{1} & contant & 0.057 & 0.067 & & 0.84 & 0.402 \\
\hline & RSC & -0.009 & 0.002 & -0.307 & -4.136 & 0 \\
\hline \multirow[t]{3}{*}{2} & contant & 0.197 & 0.094 & & 2.091 & 0.038 \\
\hline & RSC & -0.009 & 0.002 & -0.310 & -4.22 & 0 \\
\hline & AGE & -0.018 & 0.008 & -0.155 & -.106 & 0.037 \\
\hline \multirow[t]{4}{*}{3} & contant & 0.163 & 0.095 & & 1.721 & 0.087 \\
\hline & RSC & -0.009 & 0.002 & -0.315 & -4.325 & 0 \\
\hline & AGE & -0.018 & 0.008 & -0.157 & -2.150 & 0.033 \\
\hline & IND & 0.084 & 0.04 & 0.154 & 2.109 & 0.037 \\
\hline
\end{tabular}

One year after listing, WR less than 1 and we obtain a three-year wealth relative of 0.6826 .

(2). In order to reduce the influences of incorrect model setup errors on the research results, we also use matching firm approach to measure long-run abnormal returns, we also found the CAR over one year after listing is found to be $-10.89 \%$, with a t-statistic of $-2.495 \%$, two years afterlisting is found to be $-19.23 \%$ with a t-statistic of
$-4.094 \%$, three years after listing is found to be $-28.86 \%$ with a t-statistic of $-5.261 \%$. The BHAR is significant at the 0.1 level only for the first year and the long-run return is $-6.14 \%$.

(3). By looking at the market adjusted buy-and-hold return for the three year aftermarket period, and using a cross-sectional analysis, we have a better understanding of the long-run performance of Chinese IPOs. From the 
characteristic of a firm, the ones with more government ownership, traditional industry features and the shareholding reform made later are better performs.

The results show that China's IPO performed better than market index returns and the returns of matching firms within a short period after listing (6 months) but exhibited significant underperformance in the long run. The results obtained from this study provide important information for prospective investors in new issuers to understand better the Chinese IPO markets. As we mentioned before, the aftermarket underperformance is appeared not unique to the developed market, like US. It also exists in a number of countries, like Canada, Japan and so on. Chinese IPO market is still a emerging market and is small relative to the overall economy and many structural and institutional problems remain, but it appears that the development of the market is approaching maturity, holding out promising long-term prospects.

\section{Acknowledgement}

I would like to thank Professor Hamada Yasuyuki for a number of helpful comments on my paper. I also thank my research lab colleagues for their friendship. All errors are the author's responsibility.

\section{REFERENCES}

[1] Aggarwal, R., R. Leal and L. Hernandez, The After-market Performance of Initial Public Offerings in Latin America, Financial Management, Vol,22, 1993, pp.42-53.

[2] Barber B., Lyon, J. Detecting long-run abnormal stock returns: the empirical power and Specification of test statistics, Journal of Financial Economics,Vol.43, 1997,pp.341-372.

[3] Cai, J., and K.Wei.. The investment and operating performance of Japanese IPO, Pacific Basin Finance Journal, Vol.5, 1997, pp.389-417.

[4] Chan, K., J.B. Wang and K.C. Wei, Underpricing and Long-term Performance of IPOs in China, Journal of Corporate Finance, Vol.10, 2004, pp.409-430.

[5] Fama, E.F., Market Efficiency, Long-term Returns, and Behavioral Finance, Journal of Financial Economics, Vol .49, 1998, pp.283-306.

[6] Hanley, K., The Underpricing of initial public offerings and the partial adjustment phenomenon. Journal of Financial Econ, Vol. 34, 1993, pp.213-250.
[7] Keloharju, M.. The winner's curse, legal liability, and the long-run price performance of initial public offerings in the Finland. Journal of Financial Economics, Vol.34, 1993, pp.251-277.

[8] Kim, J., I, Krinsky, and J.Lee. The aftermarket performance of initial public offerings in Korea, Pacific Basin Finance Journal,Vol.3, 1995, pp.429-448.

[9] Kooli,M., and J.M.Suret. The aftermarket performance of Canadian IPOs. Journal of Multinational Financial Management: Forthcoing, 2003.

[10] Kothari, S.P. and J.B. Warner, Measuring Long-horizon Security Price Performance, Journal of Financial Economics Vol.43, 1997, pp.301-340.

[11] Loughran,Tim, Jay R.Ritter, Kristian Rydqvist, “Initial Public offerings: International Insights”, Pacific Basin Finance Journal,Vol.2, 1994, pp.165-199.

[12] Levis, M., The Long-run Performance of Initial Public Offerings: The UK Experience 1980-1988, Financial Management, Vol, 22, 1993, pp.28-41.

[13] Ljungqvist, A.. Pricing initial public offerings: Futher evidence from Germany. European Economic Review, Vol.41, 1997, pp.1309-1320.

[14] Loughran, Tim, Ritter J. "the new issues puzzle”, Journal of Finance, Vol.50, 1995, pp.23-51.

[15] Loughran, T., J.R. Ritter and K. Rydqvist, International Public Offerings: International Insights, Pacific-Basin Financial Journal, Vol. 2, 1994, pp.165-199.

[16] Michael Firth an Analysis of the stock market performance of new issues in New Zealand, Pacific Basin Finance Journal,Vol.5, 1997, pp.63-85.

[17] Lyon, J., B. Barber and C.L. Tsai, Improved Methods for Tests of Long-run Abnormal Stock Returns, Journal of Finance, Vol. 54, 1999, pp.165-201.

[18] Mok, H.M.K. and Y.V. Hui, Underpricing and After Market Performance of IPOs in Shanghai, China, $\mathrm{Pa}$ cific-Basin Finance Journal, Vol. 6, 1998, pp.453-474.

[19] Ritter, Jay R. "The long-run performance of initial public offerings”, Journal of Finance, Vol.46, 1991, pp.3-27.

[20] Sun, Q. and H.S. Tong, China Share Issue Privatization: The Extent of its Success, Journal of Financial Economics, Vol .70, 2003, pp.183-222.

[21] Tian, G., State shareholding and the value of Chinese Firms, Working Paper, London Business School Wong K, Tan R, Liu W.2006, The cross-section of stock returns on the Shanghai stock exchange. Rev Quant Financial Account, Vol, 26, 2000, pp.23-39. 